\title{
Between Hagiography and Insanity: Refracting Political Violence in William Trevor's Elegiac Fiction
}

\author{
Angelo Monaco \\ University of Pisa, Italy
}

Copyright (c) 2019 by Angelo Monaco. This text may be archived and redistributed both in electronic form and in hard copy, provided that the author and journal are properly cited and no fee is charged for access.

\begin{abstract}
This article explores William Trevor's depiction of hagiography and insanity in a body of novels and short stories portraying the violent intrusions of history in the lives of ordinary individuals. It is contended that at the core of Trevor's fiction lie traumatic experiences coming to the surface when controversial Anglo-Irish history penetrates personal identities and that, in portraying the vulnerability of such precarious human conditions, an elegiac mode emerges. On the one hand, the article illustrates how hagiography and insanity contribute to amplify and mimic the destructive effects of historical frictions. By this it is meant that the fragmented syntax, the temporal disarray and the almost mute perspective of Trevor's elegiac characters provide instances through which public traumas are acted out into the realm of the private. On the other hand, it is claimed that the very fact of embracing the wounds is an ethical gesture reminding readers of the restorative power of hagiography and insanity. It is finally suggested that one possible function of Trevor's elegiac temper is to raise consciousness, implying that his eccentric characters issue an invitation to take account of the sense of loss informing his œuvre, where political violence is eventually compensated.
\end{abstract}

Key Words. William Trevor, History, Vulnerability, Insanity, Hagiography, Trauma Studies.

Resumen. Este artículo explora la representación de hagiografía y demencia en las novelas y relatos cortos de William Trevor en las que se describen las intrusiones violentas de la historia en la vida de gente corriente. Se sostiene que en la base de la ficción de Trevor subyacen experiencias traumáticas que afloran cuando la controvertida historia anglo-irlandesa penetra en una serie de identidades personales. Al representar la vulnerabilidad de estas condiciones humanas precarias, surge una forma elegíaca. Por una parte, el artículo muestra como la hagiografía y la demencia contribuyen a amplificar y replicar los efectos destructivos de las fricciones históricas. Con esto se quiere explicar que la sintaxis fragmentada, el desorden temporal y la perspectiva casi muda de los personajes elegíacos de Trevor ofrecen ejemplos a través de los cuales los traumas públicos son escenificados en el ámbito de lo privado. Por otra parte, se afirma que el hecho de aceptar las heridas es un gesto ético que recuerda a los 
lectores el poder restaurador de la hagiografía y la demencia. Finalmente, se sugiere que una posible función del carácter elegíaco de Trevor es la de concienciar al lector, implicando que sus personajes excéntricos proporcionan una invitación a considerar el sentido de pérdida presente en su obra, en la que la violencia política se compensada en última instancia.

Palabras clave. William Trevor, historia, vulnerabilidad, demencia, hagiografía, estudios de trauma.

In his more than a half-century long career as a fiction writer, William Trevor has constantly addressed political violence against the backdrop of the ongoing tensions between Ireland and England. Historical frictions and tragic situations loom large in his novels and short stories, albeit the private domain is generally paramount, a stance that the Irish writer well illustrates in an interview to the Paris Review where he states that "[t]he struggle in Ireland, and the sorrow, is a very good backdrop for a fiction writer", yet concluding that "[h]uman reasons ... are more interesting than political ones" (Stout).

Whereas Trevor's auvre is imbued with images of suffering and loss, the historical sphere, with the wounds and pain it generates, frequently percolates through his tales. Born to Irish Protestant parents in Mitchelstown in 1928, but British for his upbringing, Trevor has benefited from such an in-between position: as an "outsider" (Stout), he has delved into the complex and contradictory Anglo-Irish relations, specifically focussing on the Ascendancy through the trope of the Big House. ${ }^{1}$ While his early works are set in South-East England, where Trevor lived for over fifty years until his death in 2016, his late fiction has gradually engaged with Irish history through the adoption of the motif of decayed Georgian mansions.

In so doing, Trevor has explored the traumatic consequences of sectarian violence affecting vulnerable subjects, specifically children, bachelors, and elderly people, in order to shed light on marginalised individuals and on how they cope with the wounds inflicted on them by history. With an interest on weird and eccentric human traits, Trevor contaminates official history and public domain with idiosyncratic and quirky elements, thus creating counter-narratives that zoom in on unusual and vulnerable aspects of the human soul. To use Elmer Kennedy-Andrews's words, Trevor's writing "coming to the collective via the individual, responds to political violence by counting the personal cost (in psychological, emotional and moral terms) of political commitment and political action" (56). His narrative art intersects public and private spaces and focuses on the possibility of bringing forth redemption and consolation in light of traumas, displaying the transformative power of literary imagination.

One main strategy Trevor adopts is that of creating awkward subjects that, with their unusual behaviours, transgress and challenge what trauma studies experts, like Judith Herman, see as the "unspeakable" (148) nature of traumas. While it is true that traumatised people may fail to understand the horrors of history and that "[t]he ordinary response to atrocities", as Herman observes, "is to banish them from consciousness" (1), Trevor's characters tend to resist trauma through idiosyncrasies and eccentricities. In oscillating between traumatic history and personal sense of loss, Trevor's fiction adheres to the traditional elegiac mode. By resorting to the main ingredients of the genre, a saturation with the past, the witnessing to traumatic events, the fascination with melancholia, and the mourning for beloved people and lost cultural values, his narratives register the impact of loss but they also open up to relationality and consolation. Even if the case studies analysed here the short stories "Saints" (1981) and "Lost Ground", and the novels Fools of Fortune (1983) and The Story of Lucy Gault (2002) - differ in the distribution of loss and pain, they share an 
elegiac orientation insomuch that saints and insane characters provide an aesthetics of compensation to trauma. ${ }^{2}$

In Trevor's macrotext, hagiography and insanity constantly recur. Albeit his Protestant upbringing in a Catholic country, Trevor has pointed out his lack of religious belief. "I don't really think of myself as religious" (Stout), he explains in the interview to the Paris Review, a point which does not entail an anti-religious perspective. His treatment of saints is in fact informed by an awareness of their human side: "somewhere in the entanglements of exaggeration and myth", Trevor argues, "there is a whispering insistence that human goodness is what matters most of all: however faint, it's a sound to honour with the benefit of the doubt" ("Lives"). If the inclination to tell stories arises from the need to investigate such human feelings as goodness and wickedness, the aspiration to truth passes also through the knowledge of the most unusual sides of human behaviour, "hot spots" ("Lives") that a novelist allegedly has to explore. Many of Trevor's novels and short stories feature saint-like creatures or mentally insane characters that, in the ongoing tensions between remembering and forgetting, mimic the repetition-compulsion typical of post-traumatic stress disorder (PTSD), illuminating the bleakest episodes of their lives. It appears that such weird voices, halfway saints and mentally ill, dwell in a sort of limbo between past and present, reality and imagination, public and private domain. In juxtaposing martyr-like subjectivities with scenes of death and war, Trevor achieves more an ethical and political function rather than an aesthetic one. These subjects thematise and give voice to political violence and human vulnerability. Owing to the poetics of vulnerability recalled here, Trevor's fiction can fit in with what such scholars as David Eng and David Kazanjian (2003), Sara Ahmed (2004), and Jean-Michel Ganteau (2015) identify as the ethical implications of loss and pain inasmuch as they become unexpectedly 'enabling' rather than destructive. Despite disclosing loss and pain, the case studies examined here are also invested in moments concerned with the power to move from the interior to the exterior, promoting interconnectivity and relations.

In this article, it is showed how hagiography and insanity refract political violence, providing an instance of compensation to historical traumas. By this it is meant that the body of Trevor's works under scrutiny not only illustrates but also animates the wounds they convey. By exposing vulnerable subjects, on the brink of human sanctity and mental insanity, Trevor's tales perform trauma and healing at the same time. If, on the one hand, the fragmented syntax and half-silent perspective of these personae is a form of "acting-out" evoking the violent scenes narrated, the very fact of embracing the wounds is an ethical gesture reminding readers of the compensative power of "working through" trauma. ${ }^{3}$ In particular, it suggested that one possible function of Trevor's stories is to raise consciousness, implying that his eccentric characters, by resorting to sainthood and mental confusion, issue an invitation to take account of the traumatic episodes of that controversial Anglo-Irish history he has attempted to describe throughout his axuve. Not only do the works analysed here pose questions about the sense of history and its impact on human psyche, they also contribute to move beyond trauma, illustrating how both victims and perpetrators may engender forms of solidarity and, more significantly, of self-definition. To do this, Trevor depicts experiences of martyrdom, hallucinations and insanity as a form of vulnerability which resists the nightmare of history: over the idea of trauma as "unspeakable", Trevor's intratextual insistence on such fictional strategies challenges the idea that traumatic history is unspeakable per se, thus illustrating, in line with Herman's stance, the compensative power of literature. 


\section{Postcolonial Traumas, Temporal Disarray and Hagiographic Revelations}

The contrast between the choice of clinging to a colonial and nostalgic past and the possible reconciliation between Catholics and Protestants informs Fools of Fortune. In this novel, one finds the problematic legacy of postcolonial history, the destructive consequences of the public domain over the private, and the motif of saint-like insane characters. Fools of Fortune is the first book of a trilogy dedicated to the Irish Ascendancy and the trope of the Big House, together with The Silence in the Garden (1988) and The Story of Lucy Gault (2002). The three novels are all concerned with traumatic history and the politics of trauma fiction, while also recalling the genre of the Big House for the use of the main conventions of the genre: remote rural settings, decayed mansions as symbols of a colonial past, and a rising Catholic middleclass. Fools of Fortune also presents an experimental narrative format that Trevor had initially attempted in "Saints", the story which came to function as the basis for the novel.

Published in the Atlantic Monthly in 1981, "Saints" was never reprinted in any of Trevor's following collections, but it was partially incorporated into Fools of Fortune, specifically in the two sections narrated by Willie. In the story, it is Josephine, the maid at Kilneaghn - the big house in decline against which the novel is set - who embodies holy qualities. Once she becomes insane, the lady is taken to an asylum where she is assumed to be able to heal ill people, until Josephine is finally sanctified. In Fools of Fortune, instead, Trevor transfers such a saintly power to Willie's daughter, Imelda, while the maid of the house, Josephine, similarly preserves a healing gift: her death eventually reconciles Willie with his daughter Imelda and his lover Marianne after a long exile. Unlike the "self-indulgent and perversely obsessive narrator" (Dantanus 169) of "Saints", Fools of Fortune features a complex narrative frame where first-person perspectives alternate with an external viewpoint.

As the title indicates, Fools of Fortune bears an intertextual link to William Shakespeare's Romeo and Juliet. ${ }^{4}$ On the one hand, in Trevor's revisiting of Shakespeare's tragedy we witness the precariousness of a love story hindered by two feuding families; on the other, Trevor amplifies the tragic tones of human pain by intermingling first-personal memories and testimonies that revolve around such critical historical moments as the Easter Rising, the War of Independence, the Great Famine in 1845 and proceeding, even backwards, to 1770 when Kilneagh had been built. Divided in six sections, entitled after the three main characters, Willie, Marianne and Imelda, the novel unfolds along two main temporal axes, starting the narrative in a flashback and ending where it begins: it opens on a day in 1983 when Willie Quinton chronicles the joined vicissitudes of his Anglo-Irish family and of the English Woodcombes, to whom the Quintons have been bound by blood and kinship since 19th century. The remaining five chapters focus once more on Willie and twice on Marianne Woodcombe, his English cousin and lover, while two brief chapters depict Imelda's perspective. Though Willie and Marianne's viewpoints are dominant, and their relevance is reflected in the first-person narration, Imelda, who is insane and almost mute, is given voice through an omniscient external perspective which filters the story through the eyes of an innocent child.

"Imelda Quinton is my name, Ireland is my nation. A burnt house is my dwelling place, Heaven's my destination" (Trevor, Fools 155). Imelda's response to her family and national traumas is conveyed through a visceral viewpoint constructed of short sentences and contrasting images which reflect fractures within the self. The off-spring of two families feuding for generations, belonging to two countries into a never-ending fight despite Ireland and England "seemed like lovers" (162) on the map, is emotionally traumatised. The girl is an indirect witness to scenes of violence, not only in the form of reveries but also in everyday life, as while roaming the fields: "[s]he asked forgiveness if she stepped on a snail", the narrator observes, because she is aware that "a snail was just as much God's creature as 
anything else was" (158). Whereas David Mason has emphasised that Imelda's elegiac search for care entails "a kind of mercy" (313), hinting at the possibility of forgiveness and redemption, for Constanza del Río-Álvaro the child is "frozen in time" (14), a victim of trauma who fails to come to terms with the past and "cannot offer any hope for the future" (12). Thus, Imelda is a wounded character and the eternal return of a haunting past allows for traumas to emerge, exposing human fragility, but such temporal disarray also affects the very narrative frame.

In the novel, Trevor subverts the chronological linearity typical of the traditional Big House genre by resorting to fragmentation and intrusions: ${ }^{5}$ Willie's recollections are generally interspersed with analepsis that randomly and chaotically come to the surface. The traumatic event around which the whole story revolves, triggering all the subsequent acts of brutality, is the arson that takes place at Kilneagh, in the aftermath of the Easter Rising, by a squad of Black and Tan. During the arson Willie loses all his family, except for the maid, Josephine, and his mother, who becomes alcohol-addicted and eventually commits suicide. The episode generates feelings of revenge, while flashbacks continuously disrupt the temporal progression of the novel and move its axis towards the remote past of the ancestors of the two families, thus offering the reader a complex jigsaw of narrative pieces that ultimately find a sense at the end of the novel.

Although the narrative structure well exemplifies the complexity of the novel and the harrowing effects of historical conflicts that tend to extinguish the possibility of giving voice to pain and trauma, hagiographic elements and insanity work as compensative strategies allowing for reunion and interconnectedness. In the aftermath of his revenge on the leader of the Black and Tan squad, Willie leaves his native country for Italy where he eventually finds shelter in Sansepolcro, near Arezzo. Here, in the birthplace of the Italian pre-Renaissance painter Piero della Francesca, Willie's journey marks a new beginning. The reference to painters and the holy atmosphere of the place contributes to a sort of healing process that can be confirmed by the language of hagiography:

I returned to Italy, to my world of Ghirlandaio ... to the saints that Italy honours so: the Blessed Imelda of Bologna whom Josephine mentioned, whose day my daughter shared; St Clare who saved the city of Assisi; St Catherine who cut her hair off so that no one would wish to marry her. St Crispin was a shoemaker. St Paul made tents. A spring gushed in the desert when St Euthymius prayed. The dead body of St Zenobius revived a withered tree. Late in my life I had grown to admire the saints. (Fools 182)

The passage quoted here establishes clear parallels between Willie's mystical experience and hagiographic accounts. According to Gregory Schirmer, "[t]he innocence-experience paradigm is essential to the expression of this tragic vision of human beings as fools of fortune" (149) and the Italian setting reminds Willie of the humanist values of charity and forgiveness despite the chain of pain and destruction generated by history. By evoking images of martyrdom and sanctity, the novel activates an "ethics of vulnerabilty" (Ganteau) where attentiveness to precariousness eventually emerges. Trevor's appropriation of hagiography, therefore, establishes an elegiac tone in the novel: the obsession with the past is replaced by a sense of care towards the world and the fragile lives of the saints give form to Willie's inner metamorphosis. He starts, for instance to concern himself with the admiration and preservation of natural elements: vines, olives, Canary roses, irises and wisteria (Fools 182) provide the means through which some consolation can be found, making transformation possible. 
In invoking the compensative power of sanctity over the public domain, Willie also draws upon the moral teachings of Father Kilgarriff. The Catholic priest was his tutor, teaching him the power of history and lecturing about pacifism in such heroes as the reformist Daniel O'Connell, "who had brought freedom to the Catholics of both Ireland and England and had not cared for violence either" (12). While such non-violent attitude fails Willie when he revenges the arson, the Italian exile, instead, asserts the primacy of individual identity over the question of collectivity. If the contrast innocence-experience pervades the novel, Willie's contemplation of hagiography offers a way of understanding traumatic experience, allowing himself the possibility of relief and forgiveness against the anxieties lying behind the struggle between Catholics and Protestants, a point that the novel constantly reiterates, as when a nun warns Will about the importance of studying the lives of the saints so that "you'll find that it is horror and tragedy that make them what they are" (183).

If temporal disarray and psychological fragmentation indicate a measure of narrative condensation that haunts its victims, Imelda, instead, reveals some resilience with her name and her insane nature. As suggested before, the child who dwells in a sort of limbo, in a decayed Kilneagh, with her mother Marianne, waiting for the return of her father. By reading the diaries of her mother and listening to her recollections, Imelda constantly visualises speechless flashbacks, conjuring up images of bodies enveloped in flames. Interestingly, Imelda confusedly recites verses from W. B. Yeats's poem "The Lake Isle of Innisfree", a pastoral on Ireland connected to feelings of hope and peace. While Richard Russell contends that her beatitude is the false portrait of a tragic heroine for whom "horrors have literally become embodied" (75), her name instead unveils a kind of salvific mystery. A visionary character, named after the blessed Imelda Lambertini ${ }^{6}$, in her middle-age Imelda "does not speak at all" (Fools 205), but she is endowed with the power of healing ill people: "a woman has been rid of dementia, a man cured of a cataract" (206), the narrator reports. As an observer of her family's ruin, Imelda's final silence is a vibrant manifestation not only of the wounds of characters caught in the throes of historical and political upheavals, but also of the vulnerability of a narrative form compounded of gaps, fragments and hallucinations. Imelda's perspective, therefore, is conceptualised as a metonymic signifier of both Irish history and elegiac writings conjuring up "the extremity of traumatic pain, itself evocative of the havoc inflicted by loss" (Ganteau 96). Her insanity is perceived as "a shroud miraculously about her, its source mysterious except to her" (Fools 206). Though mute, Imelda discloses some hope for the future of her country with her saintly gifts, echoing what Herman would say about transcending traumas "by making it a gift to others" (207). Imelda's "survivor mission" (207) takes the form of a human martyr with holy powers bestowed on her. Elegiac lamentation, hence, makes space for reconnection with others, turning pain into action and thus moving beyond melancholic loss.

Despite the violent intrusions of history into the private sphere, insanity and sainthood provide a way out from the tyranny of nationalism and collective identity. Willie's remark, "it happens sometimes that the insane are taken to be saints of a kind. Legends in Ireland are born almost every day" (Fools 198), then opens up to the metamorphic force of vulnerability.

\section{Religious Conflicts and the Ethics of Loss}

In a similar way to Fools of Fortune, the short story "Lost Ground" documents the struggle to find personal identity against the rhetoric of national collectivity. In the tale, Trevor employs hagiography and human vulnerability to capture the traumatic intersection of history and subjectivity. The story, which is part of his ninth collection, After Rain (1996), ${ }^{7}$ features a Protestant family, the Leesons, in a deeply Catholic country. Set in Northern Ireland between 1989 and 1991, a period marked by increasing Anglo-Irish tensions, "Lost Ground" 
interrogates human passions and the legacy of historical traditions. The Leesons epitomise the typical Ascendancy family and their mansion well exemplifies the genre of the Big House. "Generations of the family", the third-person omniscient narrator observes, "had lived in this kitchen, ever since 1809" (Trevor, "Lost Ground" 108). Despite the various historical events, the house was rebuilt in 1931 and it "still stood white and slate ... the land well tended ... reflecting the hard-working Protestant family the Leesons were" (108). Every July, the Leesons take part in the celebration evoking the victory of the Protestant forces under King William III at the Battle of the Boyne, in 1690, as a symbol of colonial legacy.

On the afternoon of 14th September 1989, the not yet sixteen-year-old Milton Leeson receives the visit of a woman in the orchard of his house. The woman, whom he thinks is stealing apples from the trees, kisses him and during the second encounter, on the following day, she confesses to be St Rosa, while Milton "had the distinct impression that the woman wasn't alive" (110). Mesmerised by the apparition, Milton does not share his secret with anyone for over ten months, though the memory of the woman continues to haunt him. Eventually, he talks to Father Mulhall and the Catholic priest is astonished at such a confession: unaffected by the boy's stammering speech, "beginning sentences again ... his meaning slipping away" (119), Father Mulhall wonders: "[w]hy should a saint of his Church appear to a Protestant boy in a neighbourhood that was overwhelmingly Catholic, when there were so many Catholics to choose from?" (120). The situation envisaged here - a Protestant boy describing a holy apparition to a Catholic priest in a country troubled by religious conflicts - is symptomatic of the main enunciative structure of the story where a young boy addresses adults through an account full of gaps and uncertainties, in which reality and imagination blur the borders between personal identity and the public domain of national belonging. If collective identity implies exclusion insofar as the sense of belonging to one group or the other is based on specific tenets, "Lost Ground" hints at the cultural divide between the two sides of the same country. When Milton eventually reveals his experience to his family, including the visit to Father Mulhall, and explains his ungovernable impulse to preach, the Leesons see the boy as a threat to the preservation of that public collective identity they have always symbolised.

Milton roams his neighbourhood, preaching that "St Rosa could forgive the brutish soldiers and their masked adversaries" (124). As Imelda indirectly calls for forgiveness, Milton conveys a similarly challenging message. Yet, unlike the child in Fools of Fortune, Milton's fate is a sinister one. Embarrassed by their son's insanity, the Leesons lock him up until his elder brother finally kills him, preferring collective discourse to individual freedom: "Milton's death was the way things were, the way things had to be: that was their single consolation. Lost ground had been regained" (132), the narrator finally concludes.

Thus, Milton becomes the sacrificial victim of the conflict between private and public domains and his story unveils an overall tragic idea of history. The search for individual subjectivity marks a first step towards grief and pain and, as Fitzgerald-Hoy argues, "[t]he Leesons' desperate attempts to salvage their reputation result in a decidedly Pyrrhic victory. Their farm ... will become 'lost ground"' (44) since Milton's elder brother will sell the house, while the youngest son has Down syndrome. While Fitzgerald-Hoy's words convincingly reflect the deep pessimism of the conclusion, the perception that "those who lock their identity in a vanishing past are doomed to exclusion from Ireland's future" (45) suggests that what Trevor portrays is definitely concluded. The fact that the ground is lost and that Milton has been shot by his brother is a dark shadow that in fact begs investigation: at what cost has the ground been regained? Is collective identity the alternative to difference and otherness?

As one can easily infer, "Lost Ground" poses more questions than it can ever aspire to answer. On the one hand, the use of hagiography serves a moral purpose. As St Rosa of Viterbo (1223-1251) - who died as a young girl in a town upset by the struggle between 
Papists and supporters of the Holy Roman Emperor Fredrik II - used to instruct people to penitence, so Milton's preaching captures the climate of fear, "the weapon of the gunmen and of the soldiers" ("Lost Ground" 127), that dominates his times torn between individual and collective identity. Over a dominant mode of fear and exclusion that unquestioningly marks Ireland, Milton discloses a self-reflexive awareness in which his marginalised subjectivity challenges conventional discourses of tradition, while acknowledging that resistance is yet possible. On the other, the binary opposition between gain and loss needs to be readdressed from the point of view of the reader rather than of the characters. "Lost Ground" traces the aftermath of Milton's vision, forcing the reader to question his insanity with reference to the illogical evils of exclusion. Passing from the realm of the living, which is nevertheless redolent of pain, into a hallucinatory environment that challenges the imposition of fear, Milton's experience allows readers to decide whether madness lies in his visions or in the controversial actions of the other characters. A sort of double of St Rosa, Milton delivers sermons with a voice that seems to come "from somewhere outside himself" (124): he dwells on a threshold between sanctity and humanity that contaminates the narrative, leaving the question of the spectral vision unresolved while also embodying a function of alterity. In Ganteau's words, a ghost-like creature is "an agent of vulnerability" (115) reminding readers of the human fragility and their need of relationality. If the ghost is "a figure of responsibility" (125) and those who are visited by ghosts share "a similar sense of responsibility for the other" (125), then Milton's tale of loss discloses glimpses of future hope. While a certain elegist sense of surrender seems to be prevalent, Milton's teachings lead to solidarity among his neighbours, favouring an enabling force of loss that "opens the present and orientates it towards unknown futures" (Eng and Kazanjian 5-6). In so doing, Trevor poses crucial questions to the understanding of eccentric subjectivities in search of a sense of the self, thus highlighting the ethic function of literary writing.

\section{The Paradoxical Quest of Lucy Gault: from Melancholia to Resilience}

The final part of the article investigates Trevor's penultimate novel, where the Irish writer makes room for more nuanced tones. Unlike the works analysed before, The Story of Lucy Gault is only reminiscent of the violent Anglo-Irish tensions since it privileges the exploration of an alienated subjectivity. A Bildungsroman of sorts, the novel, as the title itself suggests, charts the formative trajectories of the heroine, Lucy, from childhood to old age.

The Gaults have been living in Lahardane since the 18th century, but at the time when the story begins, in 1921, "[t] he style of the past was no longer possible" (Trevor, Lucy Gault 6). Once more, Trevor employs the trope of a decayed Big House as a symbol of nostalgic unity disrupted by historical upheavals. One night, when the heroine is eight, a gang of young nationalists attempts to burn Laharadane, as a symbol of that Anglo-Irish Protestant power in a Catholic country fighting for independence, and captain Edward Gault, Lucy's father, mistakenly shoots Horahan, one of the arsonists, wounding him slightly. Fearing a wave of revenge, the Gaults leave their home, but Lucy, refusing to go away, escapes. The girl, however, does not return and the fruitless searches end when her clothes are found by the shore near Laharadane. While the Gaults, devastated, leave Ireland, Lucy, who had injured her ankle, is eventually found by the Gaults' servants who raise the child, waiting for the return of her parents. One may note that the frame of the novel echoes the same pattern of Fools of Fortune, but in The Story of Lucy Gault Trevor resorts to the ingredient of resilience against wounds in a more performative way. The climax of the story is clearly stated, without the complex network of analeptic loops in Fools of Fortune, and it covers the very beginning of the novel, occupying the first chapter of the first part. The rest of the narrative chronicles 
Lucy's self-imposed exile from the world and the Gaults' peregrination through Europe, specifically in Italy.

Physical wounds proliferate in the story: Lucy's twisted ankle leaves her with a permanent limp; his father, with "fragments of shrapnel in his body" (4) is a wounded survivor of World War I; and Horahan is temporarily injured on his right shoulder. The insistence of physical pain suggests a notion of the self as a locus of liminal contradictions, hosting suffering and resistance in the attempts to reconcile personal identity and historical frictions. Among the various wounds the novel features, the most striking is the psychological vulnerability affecting Heloise, Lucy' mother. The woman blames her English nationality for the attempted arson and when the Gaults settle in the fictitious town of Montemarmoreo which foreshadows the typical Tuscan centres where Trevor himself lived at times - she connects herself to her daughter, who remains a child forever in her imagination, through the iconography of St Cecilia. The English woman cannot properly mourn Lucy and she replaces her child with the Renaissance portraits of the Italian martyr in the local church, learning about the story of her sacrifice. As the Italian saint resisted death by singing for three days, so Heloise conjures up the image of Lucy as a creature trying to overcome death, a resilience that the child shows through her self-imposed exile.

Hagiography and insanity are continuously interwoven within the plot. Whereas in her childhood Lucy is very much alike a Romantic heroine - the child lives connected to the natural world, wondering through the woods of glen, along the coastline, caring for the bees and the blue hydrangeas, in an echo of Wordsworth's Lucy - she later becomes a sort of selfflagellating victim. Lucy withdraws from the world in the microcosm of Lahardane, consumed by an intense sense of guilt, while penitence and abnegation transform her into a kind of secular saint. In her early middle age, Lucy indirectly shares her mother's fascination with saints. She lives suspended in a sort of half-life: an avid reader of Victorian novels, she wears her mother's white clothes, takes up embroidering and beekeeping, and embraces loneliness and grief. Thus, Lahardane becomes a healing place, tangential to the Anglo-Irish tensions and World War II. And yet, Lucy's concern with the preservation of the cultural and historical memory of her birthplace epitomises a melancholic attachment that is not utterly destructive. Endurance, as in the case of St Cecilia's martyrdom, presents what Eng and Kazanjian call a "palimpsest-like quality" (5) allowing for self-definition rather than pathological crisis to emerge.

In the aftermath of Heloise's death, Edward Gault finally returns to Lahardane where he finds out that Lucy is still alive. Upon receiving the visit of Horahan, who has gradually gone insane, Mr. Gault treats him compassionately, while Lucy experiences a kind of traumatic revelation. Lucy who bears the name of the saint patron of the blind, from the Latin word lux, suffers from blurred vision throughout the novel. Horahan's insanity, instead, illuminates the dark side of violence, teaching Lucy the gift of forgiveness. The feeling of speaking about all the devastation brought by the arson collapses before Horahan's muttering speech where "no sense was made of anything" (Lucy Gault 191). Such compassionate way marks the perfomative dimension of the novel: by directing Lucy's affect to the man who had triggered the Gaults' misfortunes, Trevor interrupts the melancholic impasse of the plot, thus viewing vulnerability as a position of strength rather than weakness. In Sarah Amhed's words, sharing the pain of the other means to "bear witness" (29) insomuch as the other's pain reminds us of our own vulnerability. If emotions are "what moves us" (Ahmed 27), then compassion triggers Lucy's reaction along with St Cecilia's message of forgiveness, turning passivity into action.

In her old age, Lucy regularly visits Horahan in the asylum where he has been confined. Haunted by visions of pain and torment, he dreams a drowning corpse, blaming on himself for the supposed death of a child. In addition, he prays before the image of the Virgin, 
"begging for the gift of a sign, a whisper of assurance that he was not abandoned" (Lucy Gault 124). When Captain Gault and Horahan die, Lucy temporarily leaves her isolated shelter of Lahardane and visits Montemarmoreo and the Renaissance paintings in the local church. Back to Ireland, Lucy befriends two Catholic nuns, to whom she reports the story of St Cecilia's martyrdom. A secular saint, the heroine does not resign to the destructive power of history, neither she succumbs to mental insanity. The enigma of her story shows that vulnerability may entail consolation: "[c]alamity shaped a life when, long ago, chance was so cruel. Calamity shapes the story that is told, and is the reason for its being: is what they know, besides, the gentle fruit of such misfortune's harvest?" (224). A survivor and witness to a traumatic experience, Lucy recounts her life to the two Catholic nuns who are astonished by her tranquility and wander how calamity may have yielded such peace. Trevor's postmelancholic conclusion tries then to provide an answer to the nuns' bewilderment: while Lucy longs to be relieved of her grief, the urgency to confess her story implies confronting alterity and rationality in search of truth and light.

Given the novel's emphasis on sacrifice, Lucy's association to St Cecilia, or more indirectly to St Lucia, can be read as a sign of moral sainthood, an analogy evocative of George Eliot's use of hagiography in Middlemarch (1871). In the prelude to the novel, Eliot traces a parallel between the heroine, Dorothea Brooke, and the Spanish St Theresa of Avila, who had reformed religious communities in the 16th century. By invoking the Spanish saint and her "passionate, ideal nature demanded an epic life" (3), Eliot intended to counterbalance Dorothea's failure to perform epic actions. Likewise, Lucy is a saint-like creature in the throes of historical frictions: unable to perform great changes in a historical complex era, she resists resignation through stoical suffering and redemption. In line with Herman's comments, Lucy's recovery from trauma happens in connection and reconciliation since "[r]ecovery can take place only within the context of relationships; it cannot occur in isolation" (133).

\section{Coda: the Compensative Power of Sainthood and Insanity}

Trevor's mastery of fiction, to conclude, is at its best when presenting seemingly ordinary characters able to reveal the force of pain and trauma in the moments of individual resistance to the violent intrusions of history in their lives. Whereas his stories bear some resemblance to contemporary elegiac novels, through the motifs of loss and mourning, some restorative horizons appear: the critical engagement with sainthood and insanity provide "an ethical response to loss" (Ahmed 159), allowing for "attention to remains" (Eng and Kazanjian 2). While offering different types of closure, where consolation, death and mourning respectively prevail, and by juxtaposing deep psychological realism with elegiac tones, Trevor's fiction exhibits a gaze conflating the lucid intervals of human soul and the dark sides of history. As Ganteau puts it, contemporary vulnerable characters "are endlessly exposed to the tyranny of loss, extending and straining their vulnerability, hence making it even more visible and audible" (96). Along such lines, hagiography and insanity become in Trevor's work a prism through which the incursion of political violence into individual identity is possibly refracted.

\section{Notes}

\footnotetext{
${ }^{1}$ Originally used to describe Protestant Anglo-Irish families which had settled down in Ireland since the 18th century, the term was later applied to refer to estates and mansions of families in decline.

${ }^{2}$ It would be impossible to chart all the manifestations of the saintly and awkward creatures that frequently populate Trevor's fictional world, a point that is partly explored in Tom McAlindon's "William Trevor and the
} 
Saints". Instances of insanity pervade also Trevor's long short-story Reading Turgenev (1991) and his last novel, Love and Summer (2009). Both works are based on illicit love affairs - between Mary Louise and her cousin Robert in the novella and between Florian, the young heir of a decayed Ascendancy family, and Ellie, a married unhappy woman in Love and Summer - while mental instability runs throughout the plots. Mary Louise retreats in an asylum where, in a state of apparent insanity, she conjures up poignant recollections of her past. In Love and Summer, the idyll of Ellie and Florian's romantic story is interspersed with the snapshots of a nostalgic past embodied by Orpen Wren. A sort of lost historian, the old Orpen roams the town, trying to give people old documents he has stored, and confuses Florian with the heir of the family for whom he once used to work as librarian. Among the short stories, mentions should be made of "The Virgin's Gift" and "The Dressmaker's Child": both tales, later collected in his Selected Stories, stage appearances and statues of the Virgin Mary.

${ }^{3}$ In his influential essay, "Trauma, Absence, Loss" (1999), Dominick LaCapra, drawing on Freud's theories, distinguishes "acting out", perceived as a psychic response to traumatic loss for both survivors and perpetrators for whom the past "hauntingly returns as the repressed" (716), from "working through", a process which enables traumatised subjects to cope with their grief in a more conscious way.

${ }^{4}$ The title reproduces Romeo's declaration, "O, I am fortune's foole" (3.1.136). Having killed Tybalt, the young Montague is forced to exile to Mantua, feeling like a fortune's puppet. Similarly, the phrase returns twice in Trevor's novel (Fools 41, 201) when Willie's father expresses unpredictable consequences for the future.

${ }^{5}$ Traditional Big House novels, such as the ones by Maria Edgeworth (1767-1849) and Sheridan Le Fanu (18141873), follow a realistic format where chronological order and mimetic accuracy prevail. As Vera Kreilkamp suggests in her study of the genre, contemporary Irish writers, like Trevor, shift from "the realistic novel's wideangled to psychological fiction's focus on the isolated self" (197).

${ }^{6}$ Imelda Lambertini (1322-1333) was born in Bologna to a noble family. At the age of nine, she was sent to a Dominican convent where, despite her longing, she was not allowed to receive the Holy Communion because of her young age. On the vigil of the Ascension in 1333, Imelda received the visit of a glowing light with the Sacred Host. The nuns realised that Jesus himself was satisfying Imelda's desire. A priest gave her the Holy Communion and, immediately after, Imelda died. Beatified in 1826, today she is the patroness of First Holy Communicants.

${ }^{7}$ The twelve stories all explore the lives of lonely and betrayed individuals in search of revenge or comfort. The use of hagiographical elements is also featured in the title story, "After Rain". Here, Harriet, an English spinster deceived by her lover, cancels her trip to Greece and returns to the Italian pensione where she used to spend her holidays with her parents, before their divorce. As always in Trevor's fiction, pain shows its silver linings: fascinated by the anonymous annunciation in the local church of Santa Fabiola, Harriet experiences a sort of epiphanic revelation about her alienated condition.

${ }^{8}$ Protests erupted in Ulster after the 1985 Anglo-Irish Agreement that allowed a certain control from the Republic of Ireland on Northern-Irish politics. The agreement was a blow to Northern Ireland's unionists and the Ulster Unionist Party (UUP) and Democratic Unionist Party (DUP) started to lead a campaign of civil disobedience.

\section{Works Cited}

Ahmed, Sara. The Cultural Politics of Emotions. Edinburgh: Edinburgh U.P., 2004.

Dantanus, Ulf. "The Text that Self-Destructs: Narrative Complexity in William Trevor's Fools of Fortune". Nordic Journal of English Studies 2.1 (2003): 165-192.

del Río-Álvaro, Constanza. "Trauma Studies and the Contemporary Irish Novel”. In the Wake of the Tiger: Irish Studies in the Twentieth-First Century. Ed. David Clark and Rubén Jarazo Álvarez. La Coruña: Netbiblo, 2010. 3-15.

Eliot, George. Middlemarch. Cambridge: Cambridge U.P., 1991 (1871).

Eng, David L., and David Kazanjian. Loss: The Politics of Mourning. Oakland: University of California Press, 2003.

Fitzgerald-Hoy, Mary. "William Trevor's Protestant Parables”. Colby Quarterly 31.1 (March 1995): 40-45.

Ganteau, Jean-Michel. The Ethics and Aesthetics of Vulnerability in Contemporary British Fiction. London and New York: Routledge, 2015. 
Herman, Judith L. Trauma and Recovery: The Aftermath of Violence: From Domestic Abuse to Political Terror. New York: Basic, 1992.

Kennedy-Andrews, Elmer. “'The Battlefield Has Never Quietened': Political Violence in the Fiction of William Trevor". William Trevor: Revaluations. Eds. Paul Delaney and Michael Parker. Manchester: Manchester U.P., 2013. 55-75.

Kreilkamp, Vera. The Anglo-Irish Novel and the Big House. Syracuse: Syracuse U.P., 2006.

LaCapra, Dominick. "Trauma, Absence, Loss". Critical Inquiry 25 (Summer 1999): 696-727.

Mason, David. "Forgiving the Past". The Sewanee Review 106.2 (Spring 1998): 298-316.

McAlindon, Tom. "William Trevor and the Saints". The Review of English Studies 67.282 (November 2016): 970-988.

Russell, Richard R. "The Tragedy of Imelda's Terminal Silence in William Trevor's Fools of Fortune". Papers on Language and Literature 42.1 (Winter 2006): 73-94.

Schirmer, Gregory. William Trevor: A Study of His Fiction. London and New York: Routledge, 1990.

Shakespeare, William. Romeo and Juliet. London: Norton Critical Editions, 2016.

Stout, Mira. "The Art of Fiction CVIII: William Trevor". The Paris Review 110 (Spring 1989). 22 June 2018. https://www.theparisreview.org/interviews/2442/william-trevorthe-art-of-fiction-no-108-william-trevor

Trevor, William. "Saints". The Atlantic Monthly (January 1981): 29-36.

- Fools of Fortune. New York: Viking, 1983.

Reading Turgenev. London: Viking, 1991.

"The Lives of the Saints". The New York Review of Books. 21 October 1993. 10 June 2018. http://www.nybooks.com/articles/1993/10/21/lives-of-the-saints/

- The Story of Lucy Gault. London: Viking, 2002.

- Love and Summer. London: Viking, 2009.

. Selected Stories. London: Penguin, 2011.

Received: 6 September $2018 \quad$ Final version accepted: 9 November 2018

Angelo Monaco holds a PhD in English Literature (University of Pisa, 2017). His research interests revolve around the Anglo-Indian novel, the Indian diaspora, ecocriticism, trauma studies, translingualism and transmodernity. He has written extensively on such issues as melancholia, nostalgia, globalisation and vulnerability in contemporary fiction and his papers have appeared in international journals (Commonwealth Essays and Studies, Impossibilia, Il Tolomeo, Le Simplegadi) and edited volumes (Cambridge Scholars, Liguori, Routledge, Transcript). He is the author of Jhumpa Lahiri. Vulnerabilità e resilienza (ETS Edizioni, 2019).

angelo.monaco@gmail.com 